\title{
The Challenges of Traveling a Psychospiritual Path in Today's Postmodern Western World
}

\author{
Judith S. Miller, Ph.D. \\ Columbia University
}

\begin{abstract}
Although the category "Religious or Spiritual Problem" (Code V62.89) was incorporated into the Diagnostic and Statistical Manual for mental health professionals in 1994, it has taken until 2012 for a conference or training to take place designed to help therapists and social workers understand how best to address such issues. In this article I describe my personal experience and my professional experience as a psychotherapist with religious and spiritual phenomena. I offer my view of what it means to be spiritual, including the role of worldviews and my conceptualization of a three-stage path of spiritual development.
\end{abstract}

KEY WORDS: psycho-spiritual development, Western spiritual path, worldviews, postmodernism.

I never thought that in my lifetime I would see a professional conference where psychologists and counselors would begin the process of becoming certified to work clinically with individuals who have had spiritually transformative experiences (STEs). "Religious or Spiri-

\footnotetext{
Judith Miller, Ph.D., is a professor of developmental psychology on the graduate faculties of Columbia University and the International Institute for Consciousness Exploration and Psychotherapy in Wittnau, Germany. She provides clinical supervision to psychotherapists and graduate psychology students that focuses on bridging psychology and spirituality. She also supports spiritual seekers as they travel their respective paths of psychospiritual development. She is a past Director of the International Association for Near-Death Studies and is currently on the Board of Advisors of the American Center for the Integration of Spiritually Transformative Experiences (ACISTE). She is also a member of the European Transpersonal Association and is the author of Direct Connection: Transformation of Consciousness (2000). This article is based on Dr. Miller's presentation at the inaugural conference of ACISTE in October of 2012. Correspondence regarding this article should be sent to Dr. Miller at drjudithmiller@comcast.net.
} 
tual Problem" is a diagnostic category (Code V62.89) in the fourth edition of the Diagnostic and Statistical Manual (American Psychiatric Association, 1994) for mental health professionals. Acceptance of the category was based on extensive reports of clients coming to therapists who were experiencing conflicts related either to their religious institution or to experiences and questions of a spiritual nature. Although this category was incorporated into the Manual in 1994, it has taken until 2012 for a conference or training to take place designed to help therapists and social workers understand how best to address such issues. It is with appreciation that I thank the pioneers and visionaries - too numerous to mention here-who have worked so hard for so many years to bring this development to fruition.

Why did I fly from the East coast to the West coast to attend this conference? I think my story is not all that different from many of the people here. As a young adult I started having spontaneous mystical experiences, and they were shocking to me. I was from a secular Jewish family, a newly minted psychologist, and there was nothing in my training and background to prepare me for what was happening. At the time I was working at a mental health agency with individuals who were diagnosed with serious mental illness . . many with diagnoses of schizophrenia, psychosis, and so forth. It was startling to me that my clients were talking about their religious experiences that were very similar to what I was experiencing. I was in a bit of a dilemma: I could not go to my supervisors and tell them about my experiences for fear of being diagnosed myself. It was the 1980s. There were no psychotherapists I could go to that I trusted would understand. I had a husband, two children, and two dogs, and I was trying to balance everything. I knew I wasn't mentally ill; I just knew it. But my situation was disconcerting, to say the least.

Synchronistically, just as I was feeling as unsettled as I could be, I got a brochure in the mail from the International Association for Near-Death Studies (IANDS). As I read over the material, I discovered that people who had near-death experiences (NDEs) were reporting experiences very similar to what I was going through. However, they had died, and I hadn't. So I still had a bit of a problem.

I went to an IANDS conference and became very active in the organization during the 1980s. I started counseling people who had had NDEs and eventually became president of the Philadelphia chapter and sat on the IANDS board of directors.

In retrospect, the highlight of my involvement with IANDS occurred at Barbara Whitfields's house in Florida, where a group of us 
got together on a weekend to set up professional guidelines for people who were having NDEs. Through this process, we all began to share our own personal spiritual and mystical experiences, which turned out to be similar to the NDEs we were discussing. In so doing, our previous secret fear that we were crazy began to dissolve. Here was a whole household of us, and it was quite wonderful. I believe that my spiritual path was supported and guided by spirit-and I think everyone's is, even though most people don't realize it. My attendance at that IANDS meeting, I feel, was divine intervention to provide me with a level of support and understanding that was so important to me then.

To sum up my work: For 25 years, in various ways, I have been trying to bridge psychology and spirituality. I teach at the university in an effort to foster a change in the attitudes of the next generation of psychotherapists. I have a clinical practice where I help people understand the meaning of their spiritual experiences and support them on their psycho-spiritual quests. I utilize Holotropic Breathwork (Grof \& Grof, 2010) as a tool in this process and have worked closely with spiritual seekers not only in this country but also in Europe. I have learned many things over the years.

\section{What It Means To Be Spiritual}

What I will discuss today is what it really means to be spiritual. In the 20-some years since I've been involved in this work, being "spiritual" and the subject of "spirituality" have become hot topics in popular culture. This development is apparent on on-line dating sites: "I'm looking for someone who's spiritual, not religious." And in the publishing business and the media, there is so much material available.

Not to be negative, because I do recognize how spiritual writings and discussions are clearly more prevalent than 20 years ago. But at the same time, I believe that a lot of what is being termed spiritual is very superficial and unreal.

At Columbia University, where I've been teaching for 13 years, I'm a professor in the Human Development department. Even though my training was in clinical psychology, human development has become my academic home. The reason for this evolution is because I believe that the very topic of development suggests that there is no limit to humans' potential to progress. Even so, I find it disappointing that mainstream developmental psychology textbooks focus on biological, 
psychological, emotional, and cognitive development, but they don't recognize spiritual development in any way.

This is what my teaching in academia has emphasized. I discuss with my students that spiritual development is also a part of being human. I think there's been a good opportunity to get this message across in developmental psychology because, unlike most clinical and counseling psychology programs in our nation's colleges, human development curriculum does not particularly focus on psychopathology. In much of clinical psychology and psychiatry, there is also a glass ceiling that stops at the level of a strong ego-that aspect of human personality that Sigmund Freud deemed necessary for living in the material world.

What, exactly, does being spiritual really mean? I believe that the following three principles must be adhered to if people are to successfully travel a spiritual path. It is also my belief that many individuals who call themselves spiritual get stuck on their paths because they don't acknowledge these principles:

- First, you need to be clear on what worldview you hold.

- Second, being spiritual is much more than having a spiritually transformative experience (STE), such as an NDE, or an experience of enlightenment in a workshop; you have to be committed to traveling a challenging path of inner development, which is lifelong.

- Third, you have to realize that you are engaging in a sacred process that is not to be taken casually.

\section{Worldviews}

What do I mean by a worldview? Every culture throughout time has been structured according to its particular worldview. A worldview helps us humans understand ourselves and make choices, provides us with values to hold onto, and greatly influences the ways that we live in the world. It helps us deal with pain and suffering and provides answers about faith and the meaning and purpose of existence.

When we contemplate the different worldviews across time, we discover the premodern, the modern, and the postmodern. Each of these worldviews has served as a super-theory or paradigm for interpreting human experience.

The premodern worldview describes what God is and what it's not. It cites that only institutionalized religion knows the ultimate truth and that only external authorities—religious leaders and texts-hold 
the answers. This perspective prevailed in the West in medieval times, and, as we know, it exists even today.

The modern worldview was prevalent in the 20th century and also exists today. It tells us that nothing is true unless it can be verified by the scientific method.

The postmodern view holds that there is no ultimate truth, because everything is relative and determined by individual perceptions. This is the prevailing paradigm today in most of the Western world.

Even though the premodern, modern, and postmodern views arose during different time periods, the Western world today remains deeply divided as to which worldview is defining how life should be lived and how people should think and believe. Additionally, I believe that both spiritual seekers and even teachers and leaders in the transpersonal psychology field have conflicts about which worldview they hold. And I have observed that when one is on a spiritual path, such a conflict causes the individual to get stuck in their spiritual development.

Most people feel safe and secure when those around them share the same worldview. However, when a person has an NDE or other STE, his or her worldview begins to change. And when this occurs, it can feel very threatening and even personally dangerous. Imagine what it's like when someone has a personal, transformative experience of God and feels ecstatic, while everyone around is saying that "Such an experience is crazy and the person having the experience needs medication."

As mentioned, the current worldview in much of Western culture is postmodern. It is especially prevalent in medicine, in psychology, in most of academia, and among most of our liberal and progressive friends. Again, with this worldview, there is no Ultimate Truth. It holds that everything is relative, determined by individual perceptions. And if there is no ultimate truth, then there are no absolutes. There is no higher power, no soul, no light or darkness, no good or evil, no God.

I was teaching at Columbia University recently and engaged in a discussion with a graduate psychology student in my class whom I will call Jane. She is someone who considers herself a very spiritual person. We were talking about the latest trauma in New York City in which a man raped and killed a little girl. I made the comment, "It's just shocking that there is such evil in the world."

Jane looked at me and said, "You can't really say that, Dr. Miller."

"Why not?" I asked. 
"Well," she said, "You don't know whether he was abused in his past or what influenced him to commit such a terrible deed."

"I don't care," I said. When he tortured and raped and murdered that little girl, that was evil, in my opinion."

Of course this exchange created a lively discussion in the class. This is what I'm talking about: There is a very deep confusion and conflict in people's belief systems in our postmodern Western society, even among people who consider themselves very open, progressive, and spiritual. This conflict keeps people stuck on their paths, because if there is no ultimate meaning, no recognition of forces of light and darkness, then what do they think spirituality is about?

The first thing I suggest when it comes to spiritual development is that people reexamine their relationship to 21 st-century postmodern thought. I contend that they can't be really spiritual if they accept a postmodern worldview, because it rejects all absolutes.

Therefore, to be spiritual, to really be spiritual, one needs a new worldview. The one I ascribe to I call a psychospiritual worldview:

- It recognizes that all things, including humans, are sacred.

- We are infused with spirit, or at least part of us is infused with spirit.

- It recognizes that we all have an extreme point, a deep center at the core of our being, where our personality and human nature touches the Absolute, and this is the place where one's true being is penetrated by what in the West we call God.

- God is the eternal source from which the soul draws its energy and power. When we feel cut off from God, the soul withers. When we reconnect, the soul comes alive and we grow spiritually.

I've just spoken about the relevance of adhering to a psychospiritual worldview. Such a worldview enables us to understand that our life and the spiritual path we travel are our sacred reality. And this sacred reality is the umbrella over all.

\section{Inner Development}

The second aspect of being spiritual is to acknowledge the importance of inner development. It is about finding out who we really are, our true identity.

This pursuit means we must engage in deep, inner psychospiritual work. When we do this, we recognize that as imperfect human beings, we live in a world of dualities. As such, we possess splits and dualisms. We each have what Carl Jung referred to as a shadow-those 
unconscious, difficult parts of ourselves that we keep suppressed. We also have a soul, which is light, and all spiritual traditions aim for the same thing, which is to reach that place of Oneness, where distinctions disappear and we become one with nature, with each other, with God.

To get to that place of Oneness-which in the West is called Union, and in the East, Enlightenment-I believe we have to work with our inner light and shadow in order to transcend these dualities and move beyond them to that place of Oneness. People transcend dualities by acknowledging, confronting, and working through their own psychological, emotional, personal wounds. Spiritual development necessitates this.

Western mystics used the term purification when they described their long-term spiritual process. Purification means to work through the inner shadow, the darkness. St. Teresa was fighting the devil, and the priest was throwing holy water on her, and this example of her spiritual work shows us our task as human beings.

Psychologists and sociologists pay much attention to identity formation, and some of the great psychological theorists like Erik Erikson (1963) wrote about the ways that identity is of major importance over the lifespan. In our postmodern world when we refer to identity, it's typically about gender identity, sexual orientation, racial and ethnic identity, accepting (and feeling good about) everything that makes us who we are. We are told to love and accept all parts of ourselves.

But there is one form of identity that our postmodern secular worldview excludes: spiritual identity. In the Judeo-Christian tradition, spiritual identity grows out of a mystical foundation. When we conceptualize our spiritual identity, then, as being directly connected to and One with the Higher power, there is no real separation between Judaism and Christianity. Jesus was a Jew, for goodness sake. Most of what came after in our religious institutions was about politics, ego, and power. This artificial division has remained the huge split and duality in the Western world for over 2,000 years.

All the world's sacred traditions tell us that spiritual development inevitably unfolds in the direction of love and wisdom, which in the West is referred to as Christ Consciousness. When spiritual seekers don't do the necessary inner work, then their spirituality is superficial at best.

As I have facilitated and supported deep inner work with many people in America and Europe, I have witnessed over and over again how, at one time or another, some spiritual experience reflecting their 
Judeo-Christian roots will come up from their deep unconscious. And this emergence will occur even when they identify themselves as Buddhists, Shamans, atheists, or followers of any other spiritual tradition. When they reject their birth religion for any of a number of reasons, they will then frequently turn away from their own spiritual experiences (STE) that reflect their Judeo-Christian heritage. They would much rather have a kundalini awakening or feel their chakras open than to acknowledge that the Holy Spirit was moving through them.

My experience is that when people turn away from their STE, they are thwarting their own spiritual development. They get stuck and don't move forward. Which is not to negate any other path-Buddhism, Hinduism, Shamanism, Sufism-because, as I said, they all lead us to the same place. But part of being whole and progressing developmentally means to open to, accept, and ultimately integrate whatever comes through one's consciousness-whether it be spontaneously, in dreams, meditation, breathwork, STEs, etc. It's not for us to choose what to accept or what to turn away from, because the more of our true identity we integrate into our being, our worldview, and our personality, the greater our spiritual development. I believe there is a higher wisdom that is always available to guide us to reach our human and spiritual potential. It is our task to pay attention and not to confuse the weaknesses of Western organized religion with our true JudeoChristian mystical foundation.

I believe that spiritual development varies among people. It is influenced by how seriously they pursue the process and the commitment they make to their inner development.

\section{The Spiritual Path}

Third, spiritual development from my perspective is a definite psychospiritual process. It's a complete reorganization of the self on higher levels of consciousness and, therefore, there are stages that spiritual seekers need to travel. Because of the fundamental reorganization of self, it is not a process to be undertaken lightly.

I believe that a misguided perception exists in postmodern thinking that suggests it is wrong to assume that some people are more spiritually evolved than others. Such thinking derives from the belief that we are "all the same." Whereas in our basic human core we are, of course, all connected and One, it needs to be recognized that the person who goes to a workshop and has a transcendent high for the first time is probably not as spiritually mature or developed as the individual who 
has been doing deep inner spiritual work and traveling a spiritual path for 10 years.

Additionally, I believe it is important for seekers to realize that there are stages on the spiritual path that they need to recognize and progress through. Whereas NDEs and other STEs are catalysts for spiritual growth, they are not enough. They don't make a person spiritual. People who have an experience need to realize that their NDE or other STE is a catalyst that has the potential to propel them onto a challenging path of psychospiritual development, so that they might ultimately integrate the experience into their personality and way of living.

Such work is long-term and not always easy. There are times in our lives when we can deal with these processes ourselves. At other times, we need a teacher, a spiritual counselor, a guide. Sometimes we need help identifying our areas of shadow, of woundedness, of ego, or the places where our worldviews become conflicted, for example.

My conceptualization of spiritual development has evolved from my own psycho-spiritual process, from working with hundreds of my clients in the U.S. and Europe, and also from my own research and study incorporating Christian mystical literature and the Jewish Kabbalah. As a result of all this experience, I see contemporary Western seekers following a psychospiritual developmental path that has three major stages. I should add that these stages are also adapted from British scholar and mystic, Evelyn Underhill (1911/1990), who wrote the classic work Mysticism. She identified five stages; I condensed these to three stages, in order to make what I call the "Western Spiritual Path" more understandable and adaptable for contemporary seekers.

Stage 1: Awakening. Characteristics of this first stage may include a sudden glimpse of the transcendent, a breakthrough in consciousness. This glimpse can occur through any of a number of potentially spiritually transformative experiences, such as a vision, an NDE, a big dream, a psychic or paranormal event, a synchronicity, or a religious experience.

The other common characteristic of Stage 1 Awakening is what I refer to as "Asking Big Questions." This process may occur to the individual whose life seems just fine: She has good relationships, good career, but there is an inner gnawing. The field of psychology calls this a midlife crisis, but I believe it's much more than this. I've seen increasingly that "Asking Big Questions" happens in young people as well: "What's my life about," "What happens at death," "Is there a God?" 
What are the challenges that come up in Awakening? Stage 1 can be exciting. It is not unusual for people to react to these initial spiritual experiences as being very amazing and ego enhancing. "Look who I am!" The person can feel powerful and very enlightened. He can also feel very crazy, alone, and disoriented because his worldview is shaken up. There is identity confusion, there is confusion over new feelings and perspectives versus society's views, and therefore, it is common to feel weird and alienated from others. Although "Asking Big Questions" can trigger major emotional upheaval and conflicts, there are ways to progress through Stage 1 successfully.

Resolution in Awakening requires accepting the ambiguity of not knowing, because everything cannot be solved all at once. One must be willing to remain in confusion and slowly let the old ego self and identity die. It is also important to keep in mind that support may be needed from a spiritual guide or psychotherapist. Otherwise, spiritual experiences may not be integrated into personality and daily life. It is helpful to remember that after ego death comes spiritual rebirth.

Spiritual development means to trust the process in spite of opposition from others. Most important, it is necessary to remain open and surrender to one's experiences-even when they don't fit into the ways that one sees oneself.

Stage 2: Spiritual illumination. A person who moves through Awakening in a committed, serious way will likely begin to have stronger and more profound spiritual experiences. This increase can be unsettling if the person does not realize that such experiences can be part of the developmental process. It is common to feel that there is a foot in two worlds: the physical and the spiritual.

In many ways there are feelings of being connected to God, of spiritual fulfillment, and of joy. But as in Stage 1: Awakening, there are big challenges in Illumination as well. The intensity of spiritual experiences can feel overwhelming. At the same time, the still-robust ego can't help but feel very special indeed about being spiritually advanced enough to have such experiences. One may also feel completely unworthy: "Why would God speak to silly, unworthy me?" Both sides of the coin are ego, because ego is the source of both inflation and deflation of personal identity.

The ideal psychospiritual position is neither of these extremes. The goal is to become an empty vessel with little ego to get in the way of divine energy. Once the ego has dissolved enough, then this energy will be expressed through the individual to others for healing. 
Another challenge in Illumination is telling oneself, "Okay, I've lost a lot of my ego, but I have a special and unique relationship with the Higher power." Then suddenly, all spiritual experience stops: There is a feeling of being abandoned by God and empty inside. What must be learned is that any kind of spiritual attachment, whether it's "I'm better than everyone else," or it's "I'm not worthy," must be surrendered.

In addition to mystical literature documenting this Dark Night of the Soul as a necessary phase of purification, many contemporary authors have also written about Dark Night of the Soul. I often hear from today's spiritual seekers, "Oh, I'm in Dark Night of the Soul now." "Why is that?" I ask. "Well, I broke up with my boyfriend, and I lost my job; this is really a Dark Night for me, and that means I'm going to be spiritually reborn."

"No," I tell them. What they are describing does not accurately represent the phenomenon as mystics have referred to it. Dark Night of the Soul is much more than life disappointments and travails. It is when one's relationship and connection with God suddenly seems to be over. Rather than seeing wonderful visions, for example, there is only blackness. It's the deep pain of suddenly feeling abandoned. There's no connection; many Western mystics went through years of this experience of separation, and they were desolate because of the emptiness. Thus, seekers going through this process have lost not only their psychological ego, but now with Dark Night, there's not even a spiritual ego attachment left. But there is a method to the madness. It is preparing the individual for the goal of the Western mystical path: Union.

Stage 3: Union. In this third stage, all dualities, opposites, and distinctions vanish. Boundaries disappear into Oneness with God and all beings, the illusion that we are separate from God dissolves, the "I" as a separate entity has no meaning, and there's the awareness that one's essence is pure consciousness. Spiritual union involves the union of the whole self with the divine.

In Union, ego attachment, whether to the material world or to spirit, dissolves. Union is about fully knowing that the God force in one's soul is alive and burning brightly because it is no longer being diminished by personal shadow, ego, and fears.

The question might be asked, what is the point of all this? The purpose is to follow this divine energy that is now alive within the self and to follow it wherever it leads. There is no longer any separation between the individual and God. The felt presence of God is the most 
awesome experience a human being can have. I believe that it is thisand only this - that really leads to a permanent change in the personality: to spiritual rebirth and transformation.

\section{Conclusion}

In closing, I'd like to reassert that a spiritual path is not to be taken casually. The following quote from contemporary spiritual teacher Andrew Cohen in his recent blog is applicable:

Something profound happens at a soul level when someone makes a commitment to his or her own spiritual development. And of course when you make that commitment, you don't know what you're committing to. But what you do know is that it is a commitment to that which is Absolute, to that which is non-relative, to that which means everything. Once you say yes to the Absolute, to God, there is no going back, even if you wanted to reconsider down the line. In other words, from the depths of your soul, an inner contract is signed. (Cohen, 2012)

\section{Question and Answer}

Audience member question: We're a bunch of people who have had STEs, and you say this is only the beginning of the journey, that there's a lot of work to do, and you say the individual needs to find a teacher. Where? One can go to a bookstore and take out a lot of books, and it's not going to be enough. You're talking about uncharted territory, and so where does one go to get help at your level?

Judith: My personal experience and that of the many people I've worked with over the years is that when people reach a place where they can completely trust the STE that they've had, whatever it is, and not disclaim it because it doesn't fit they're worldview, their community, etc., if they can really surrender to it and hold the discomfort, they will be spiritually guided by a sacred force, an energy beyond themselves. Whether it's by a book falling on their head that explains the spiritual experience, or a guide comes along, or a deep knowing arises within, it's really a pact that you're making between yourself and spirit. You're saying, "Okay, I'm going to trust, and surrender." 


\section{References}

American Psychiatric Association. (1994). Diagnostic and statistical manual of mental disorders (4th ed.). Washington, DC: Author.

Cohen, A. (2012). An inner contract. Retrieved from http://www.andrewcohen.com/2012/10/09/contract/

Erikson, E. H. (1963). Childhood and society. New York, NY: W. W. Norton.

Grof, S., \& Grof, C. (2010). Holotropic breathwork. Albany, NY: State University of New York Press.

Underhill, E. (1990). Mysticism. New York, NY: Doubleday. (Original work published 1911) 